\title{
Estimasi Sudut Rotasi Benda Kaku berbasis IMU menggunakan Kalman Filter
}

\author{
Lasmadi*, Freddy Kurniawan, Muhammad Irfan Pamungkas \\ Departemen Teknik Elektro, Institut Teknologi Dirgantara Adisutjipto, Yogyakarta \\ * email: lasmadi@stta.ac.id
}

\begin{abstract}
Rotation angle estimates are often required and applied to the dynamics of spacecraft, $U A V s$, robots, underwater vehicles, and other systems before control. IMU is an electronic module that is used as an angle estimation tool but has noise that can reduce the accuracy of the estimation. This study aims to develop an estimation model for the angle of rotation of a rigid body based on the IMU-gyroscope sensor on a smartphone using a Kalman filter. The estimation model is developed in a simple dynamic equation of motion in state-space. Kalman filters are designed based on system dynamics models to reduce noise in sensor data and improve measurement estimation results. Simulations are carried out with software to investigate the accuracy of the developed estimation algorithm. Experiments were carried out on several smartphone rotations during the roll, pitch, and yaw. Then, the experimental data obtained is analyzed for accuracy by comparing the built-in algorithms on smartphones. Based on the experimental results, the accuracy rate of estimation angle is $94 \%$ before going through the Kalman filter and an accuracy level of above 98\% after going through the Kalman filter for every rotation on the $x$-axis, $y$-axis, and z-axis.
\end{abstract}

Keywords - Estimasi-rotasi, gyroscope, IMU, Kalman-filter, rigid-body

\section{Pendahuluan}

Pada dekade terakhir, IMU (Inertial Measurement Unit) telah menjadi topik menarik dalam penelitian diantaranya adalah estimasi sudut rotasi benda kaku (rigid body). Estimasi sudut rotasi atau sikap (attitude) sering diperlukan dan diaplikasikan pada dinamika pesawat ruang angkasa, dinamika UAV (Unmanned Aerial Vehicle), dinamika robot [1,2], wahana bawah air, dan sistem navigasi quadrotor sebelum dilakukan pengontrolan [3]. Estimasi sudut bisa diperlukan untuk navigasi pejalan kaki [4], sinematografi professional dan bidang lain yang memerlukan teknik ini [5].

IMU adalah suatu unit modul elektronik terdiri dari kombinasi sensor accelerometer, gyroscope dan sensor lainnya. Sebuah gyroscope mengukur kecepatan sudut pada poros/sumbu tertentu sedangkan accelerometer mengukur gaya spesifik yang merupakan total percepatan relatif terhadap jatuh bebas. Sebuah gyroscope umumnya memiliki tiga serangkai orthogonal yang mengukur kecepatan sudut pada setiap sumbu $x, y$, dan $z$ [6]. IMU dengan teknologi berbasis MEMS (Micro Electro Mechanical System) memiliki ukuran kecil, ringan dan konsumsi daya yang rendah [2]. Namun, data dari sensor memiliki derau (noise) yang dapat mengurangi akurasi pengukuran.

Kalman filter adalah suatu algoritma yang digunakan untuk mengestimasi state dari sebuah sistem berbasis waktu yang diberikan oleh pengukuran yang telah lalu. Kalman filter menjadi filter optimal yang bekerja meminimalkan mean square estimation error (MSE). Sebagaimana disebutkan dalam [7], Kalman filter memiliki tingkat komputasi yang kecil, rekursif dan merupakan estimator yang optimal. Kemudian, penelitian pengembangan Kalman filter pada inklinometer berbasis inersia untuk estimasi kemiringan benda dengan sensor accelerometer triaksial dapat ditemukan dalam [8]. Sementara itu, penggunaan Kalman filter dengan sensor IMU juga telah dilakukan pada penelitian untuk estimasi jarak translasi [9].

Manuscript submitted 20 January 2021; revised 17 February 2021; accepted 18 February 2021 Published 22 February 2021; http://dx.doi.org/10.28989/avitec.v3i1.909 
Penggunaan metode varian dari Kalman filter dengan kompleksitas dan komputasi lebih tinggi dapat ditemukan pada metode UKF (Uncented Kalman Filter) [2][10], EKF (Extended Kalman Filter) [1] dan metode Complementary filter [4].

Penelitian sebelumnya oleh Trimpe dan D'Andrea berfokus pada estimasi sudut pitch dan roll dari rigid body menggunakan beberapa sensor accelerometer. Algoritma estimasi tersebut tidak menggunakan model dinamika rigid body, namun dapat diterapkan dalam kondisi statis maupun gerakan dinamis benda [11]. Sementara itu, penelitian yang dilakukan oleh Maarif, et.al. [12] menggunakan sensor accelerometer untuk mengukur perubahan sudut pada robot keseimbangan saat bergerak. Untuk mengatasi derau pada sensor, digunakan metode Kalman filter yang terbukti dapat mengurangi derau sensor. Namun, masalah pada accelerometer tiga sumbu yang digunakan untuk estimasi sudut attitude adalah sensitif terhadap reaksi medan gravitasi bumi dan percepatan eksternal (akselerasi karena gerakan benda) [8].

Selanjutnya, penelitian lain memfokuskan pengembangan algoritma estimasi sikap untuk membatasi dampak gangguan magnetik pada sensor yang biasanya terdapat di dalam gedung [4]. Sementara itu, estimasi sudut orientasi rigid body dengan magnetometer dapat ditemukan pada penelitian Sandi, et.al. [13]. Penelitian tentang aplikasi sensor IMU telah banyak dilakukan oleh penelitian sebelumnya untuk navigasi quadrotor [3], robot keseimbangan [12], monitoring perilaku roket [14], serta bidang kedokteran untuk mengukur tremor pada pasien multiple sclerosis menggunakan multi accelerometer [15].

Pada penelitian ini, bertujuan menyajikan pengembangan estimasi sudut rotasi benda kaku berbasis sensor IMU-gyroscope dengan menggunakan Kalman filter untuk rotasi terhadap sumbu $x$ (roll), rotasi terhadap sumbu $y$ (pitch) dan rotasi terhadap sumbu $z$ (yaw). Benda kaku yang digunakan sebagai objek adalah smartphone yang sudah memiliki sensor IMU didalamnya. Model estimasi dirancang berdasarkan dinamika gerak sederhana dalam model state space. Kalman filter dirancang untuk mereduksi derau pada data sensor dan meningkatkan hasil estimasi pengukuran. Simulasi diuji dengan perangkat lunak Matlab untuk menyelidiki akurasi algoritma estimasi yang dikembangkan dibandingkan dengan algoritma yang sudah ada. Hasil penelitian ini diharapkan dapat memberikan kontribusi pada pengembangan model estimasi sudut dalam state space dan Kalman filter diskret berbasis sensor IMU untuk estimasi sudut rotasi benda kaku.

\section{Metode Penelitian}

\subsection{Rotasi Benda Kaku dan Koordinat Bodi}

Benda kaku, dalam hal ini, merupakan suatu benda yang jarak antara titik-titik masa pada benda tersebut tidak berubah. Dengan kata lain, benda yang tidak berubah bentuk saat dikenai gaya luar. Sudut rotasi merupakan besarnya sudut antara benda yang mengalami pergerakan rotasi terhadap sumbu koordinat tertentu. Sudut rotasi dapat direpresentasikan dalam Euler angle yang disebut dengan sudut roll, pitch dan yaw dalam koordinat bodi. Koordinat bodi merupakan sistem koordinat yang mengacu pada benda yang bergerak.

Kerangka koordinat sensor IMU BMI160 pada smartphone (RS Note 8) dinyatakan dalam ENU (East-North-Up) yang diidentifikasi oleh sumbu $x$, sumbu $y$, dan sumbu $z$ dalam kerangka koordinat bodi [16]. Oleh karena kerangka koordinat dalam ENU, sementara hasil data keluaran dari sensor tersebut diinginkan dalam kerangka koordinat NED (North-EastDown) maka yang semula data sumbu $x$ menjadi data sumbu $y$ (pitch), data sumbu $y$ menjadi data sumbu $x$ (roll), dan data sumbu $+z$ menjadi data sumbu $-z$ (yaw). Ilustrasi pergerakan rotasi roll, pitch dan yaw pada helikopter mainan dalam kerangka koordinat NED ditunjukkan pada Gambar 1(a) dan pergerakan rotasi smartphone dalam kerangka koordinat ENU ditunjukkan pada Gambar 1(b). 


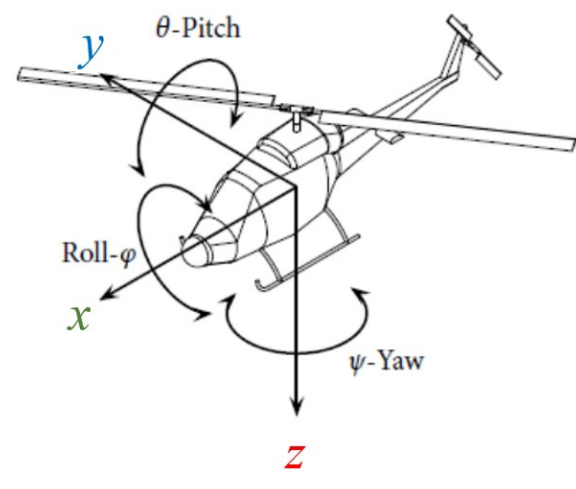

(a) NED (North-East-Down)

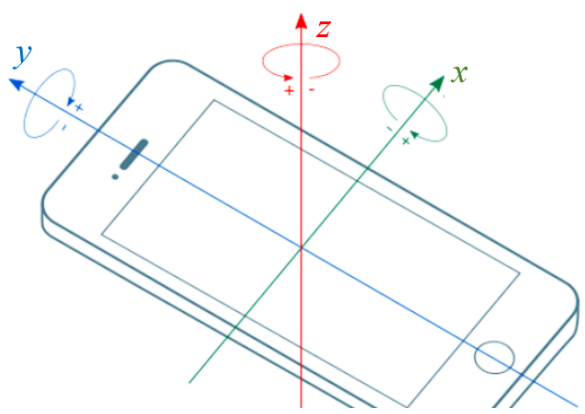

(b) ENU (East-North-Up)

Gambar 1. Kerangka koordinat NED dan ENU

\subsection{Model Pengukuran Sensor}

Konfigurasi sensor pada smartphone tersusun dari tiga serangkai MEMS (MicroElectro Mechanical Systems) yang terdiri dari sensor gyroscope 3 sumbu, accelerometer 3 sumbu dan magnetometer 3 sumbu. Keluaran sensor-sensor tersebut dapat tidak presisi akibat beberapa masalah seperti derau (noise), bias, variasi temperatur, dan lain-lain. Sensor gyroscope 3 sumbu mengukur kecepatan sudut dari smartphone dalam rad. $\mathrm{s}^{-1}$. Model pengukuran sensor gyroscope dalam waktu kontinu dapat dinyatakan sebagai,

$$
g y=g y_{t}+g y_{b}+g y_{n}
$$

dimana, gy adalah pengukuran kecepatan sudut oleh gyroscope, gy $t$ adalah kecepatan sudut true, $g y_{b}$ adalah gyroscope bias dan $g y_{n}$ adalah derau gyroscope.

Pada saat gyroscope dalam keadaan statis, seharusnya kecepatan sudut setiap sumbu adalah nol. Namun, karena kualitas sensor, pengukuran menunjukkan sebuah bias kecil (gyb). Bias ini dapat dideteksi pada keadaan statis, kemudian digunakan sebagai pengurang data pengukuran ketika mengambil data on-line.

\subsection{Pengambilan dan Pemrosesan Data}

Data keluaran sensor gyroscope diperoleh dari perekaman pergerakan rotasi benda (smartphone) pada sumbu tertentu menggunakan perangkat lunak aplikasi Sensorstream IMU+GPS secara on line (real time). Sebelumnya, perangkat lunak aplikasi Sensorstream IMU+GPS telah ter-install pada smartphone. Data diperoleh dengan merekam pergerakan rotasi objek benda kaku, dalam hal ini smartphone pada sumbu tertentu di perangkat smartphone. Data yang terekam oleh aplikasi masih berupa data dalam format .csv. Kemudian, simulasi dilakukan di Matlab dengan terlebih dahulu mengubah format data menjadi .xlsx agar dapat diolah di Matlab. Dalam kasus ini, data diolah secara off line. Skema pemrosesan data dari smartphone dan pengolahan data ditunjukkan pada diagram blok Gambar 2.

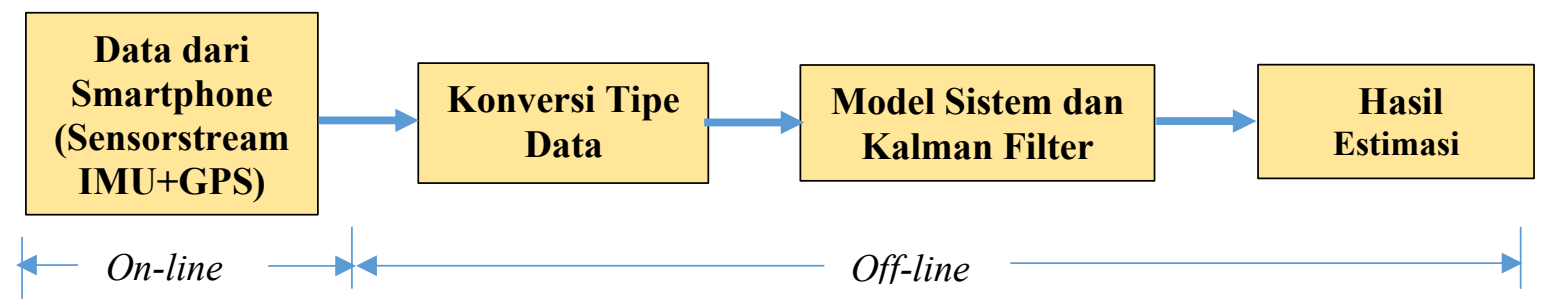

Gambar 2. Pemrosesan data untuk memperoleh estimasi sudut 


\subsection{Pengembangan Model Dinamika Sistem}

Untuk menggunakan Kalman filter pada estimasi sudut rotasi benda kaku, maka dibutuhkan model pergerakan objek. Model pergerakan objek yang dimaksud disini adalah model pendekatan yang dapat diterima, karena sulit memodelkan secara akurat pergerakan objek. Diasumsikan bahwa gerakan pada sumbu $x$ tidak berkorelasi dengan gerakan pada sumbu $y$ dan gerakan pada sumbu $x$ dan sumbu $y$ tidak berkorelasi terhadap sumbu $z$, dan mengabaikan gangguan tiba-tiba serta semua turunan yang lebih tinggi dari gerak diabaikan. Persamaan diskrit yang menggambarkan gerakan objek dapat dituliskan sebagai berikut.

$$
\begin{aligned}
& \alpha_{x_{k+1}}=\alpha_{x_{k}}+\dot{\alpha}_{x_{k}} \Delta t \\
& \alpha_{y_{k+1}}=\alpha_{y_{k}}+\dot{\alpha}_{y_{k}} \Delta t \\
& \alpha_{z_{k+1}}=\alpha_{z_{k}}+\dot{\alpha}_{z_{k}} \Delta t \\
& \dot{\alpha}_{x_{k+1}}=\dot{\alpha}_{x_{k}} \\
& \dot{\alpha}_{y_{k+1}}=\dot{\alpha}_{y_{k}} \\
& \dot{\alpha}_{z_{k+1}}=\dot{\alpha}_{z_{k}}
\end{aligned}
$$

Dimana, $\alpha$ adalah notasi sudut rotasi, $\dot{\alpha}$ adalah kecepatan sudut dan $\Delta t$ adalah durasi waktu. Sementara itu, indeks $x, y, z$ menunjukkan sumbu masing-masing dan indeks $k$ menunjukkan waktu ke- $k$. Selanjutnya, bentuk model state space dapat dituliskan sebagai berikut.

$$
X(k+1)=\left[\begin{array}{c}
\alpha_{x}(k+1) \\
\dot{\alpha}_{x}(k+1) \\
\alpha_{y}(k+1) \\
\dot{\alpha}_{y}(k+1) \\
\alpha_{z}(k+1) \\
\dot{\alpha}_{z}(k+1)
\end{array}\right]=\left[\begin{array}{cccccc}
1 & \Delta t & 0 & 0 & 0 & 0 \\
0 & 0 & 0 & 0 & 0 & 0 \\
0 & 0 & 1 & \Delta t & 0 & 0 \\
0 & 0 & 0 & 0 & 0 & 0 \\
0 & 0 & 0 & 0 & 1 & \Delta t \\
0 & 0 & 0 & 0 & 0 & 0
\end{array}\right]\left[\begin{array}{c}
\alpha_{x}(k) \\
\dot{\alpha}_{x}(k) \\
\alpha_{y}(k) \\
\dot{\alpha}_{y}(k) \\
\alpha_{z}(k) \\
\dot{\alpha}_{z}(k)
\end{array}\right]+\left[\begin{array}{ccc}
0 & 0 & 0 \\
1 & 0 & 0 \\
0 & 0 & 0 \\
0 & 1 & 0 \\
0 & 0 & 0 \\
0 & 0 & 1
\end{array}\right]\left[\begin{array}{c}
\dot{\alpha}_{x}(k) \\
\dot{\alpha}_{y}(k) \\
\dot{\alpha}_{z}(k)
\end{array}\right]
$$

Dari model state-space sebagaimana Persamaan (8) dapat ditulis sebagai persamaan linier sebagai,

$$
X_{k+1}=A X_{k}+B u_{k}
$$

Untuk menyatakan ketidakpastian (uncertainty) yang dihasilkan dari ketidaktepatan model atau ketidaktepatan data input, maka ditambahkan white noise pada model, sehingga Persamaan (9) menjadi,

$$
X_{k+1}=A X_{k}+B u_{k}+w_{k}
$$

dengan $w$ adalah derau dengan asumsi terdistribusi Gaussian dengan rata-rata 0 dan varian $Q$. 


\subsection{Perancangan Model Kalman Filter}

Algoritma Kalman filter meliputi dua langkah rekursif, yaitu prediksi dan koreksi. Pada proses prediksi, terdapat dua tahapan yaitu prediksi state dan prediksi kovarian error. Sedangkan pada proses koreksi, terdapat tiga tahapan. Tahapan yang pertama pada proses koreksi yaitu menghitung Kalman gain, kemudian tahap yang kedua dilakukan update estimasi dengan pengukuran $Z_{\mathrm{k}}$ dan tahapan yang ketiga yaitu update kovarian error. Proses Kalman filter mengalami pengulangan secara terus menerus yang dapat dilihat pada Gambar 3 [7].

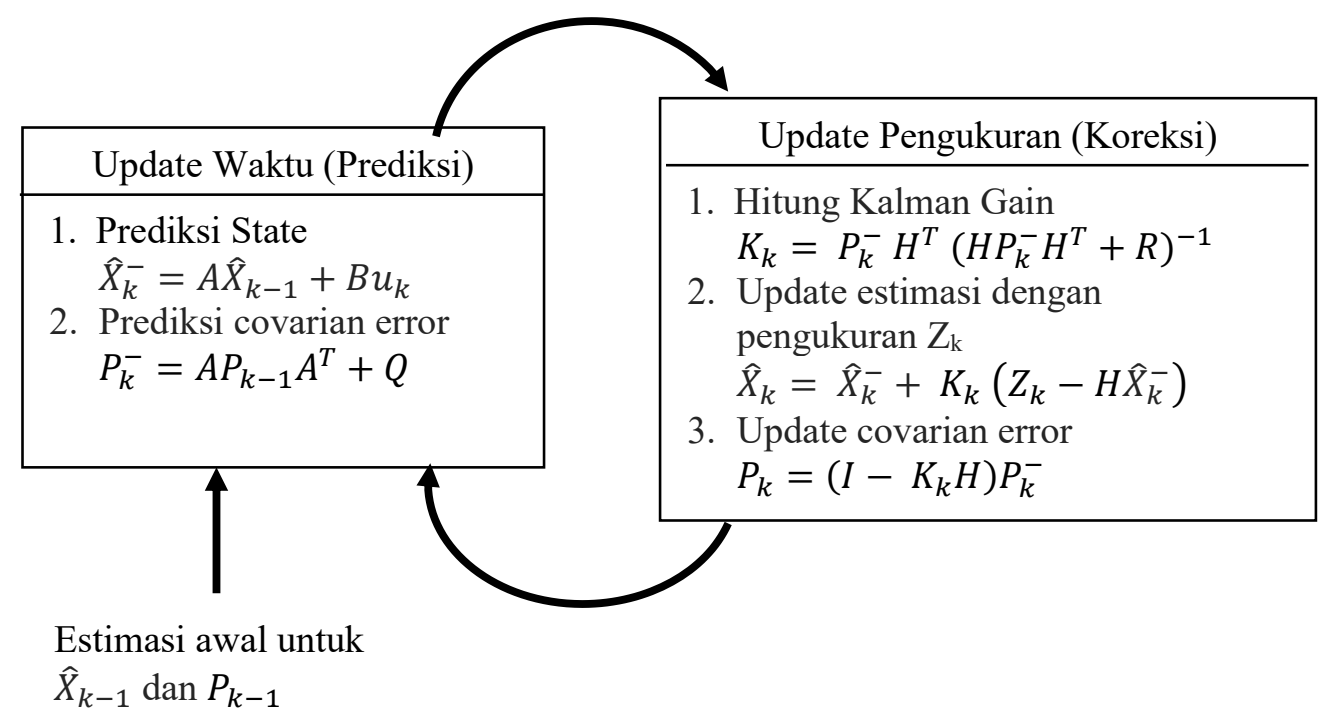

Gambar 3. Proses Kalman filter

Proses pertama pada Kalman filter yaitu menentukan prediksi state awal yang ditunjukkan pada Persamaan (11),

$$
\hat{X}_{k}^{-}=A \hat{X}_{k-1}+B u_{k}
$$

dimana $A$ dan $B$ merupakan matriks transisi, $\widehat{X}_{k}^{-}$adalah prediksi state dari sistem pada waktu $k, \widehat{X}_{k-1}$ adalah state dari sistem pada waktu $k-1$, dan $u_{k}$ merupakan masukan data dari sensor gyroscope pada indeks waktu $k$. Model matriks $A$ dan $B$ sesuai dengan model dinamika sistem pada Persamaan (8).

Setelah menentukan prediksi state awal, kemudian menentukan prediksi kovarian error yang ditunjukkan pada Persamaan (12).

$$
P_{k}^{-}=A P_{k-1} A^{T}+Q
$$

dimana $P_{k}^{-}$merupakan prediksi kovarian error pada waktu $k, A$ merupakan model dari matriks transisi, $P_{k-1}$ merupakan prediksi kovarian error pada waktu $k-1$ dan $Q$ adalah derau (noise) kovarian error. Model matriks $Q$ ditentukan dalam Persamaan (13).

$$
Q=E\left(w_{k} \cdot w_{k}^{T}\right)=\left[\begin{array}{ccc}
Q_{x} & 0_{22} & 0_{22} \\
0_{22} & Q_{y} & 0_{22} \\
0_{22} & 0_{22} & Q_{z}
\end{array}\right]
$$

dimana, $0_{22}$ merupakan matriks nol $2 \times 2$ dan $Q_{x}, Q_{y}$, dan $Q_{z}$ merupakan matriks observasi pada sumbu $x$, sumbu $y$, dan sumbu $z$. Matriks observasi sendiri dituliskan dalam Persamaan (14). 


$$
Q_{i}=\left[\begin{array}{cc}
\frac{\Delta t^{3}}{3} & \frac{\Delta t^{2}}{2} \\
\frac{\Delta t^{2}}{2} & \Delta t
\end{array}\right], \text { untuk } i \in\{x, y, z\}
$$

Selanjutnya, masuk dalam proses koreksi atau update pengukuran Kalman filter. Langkah pertama dalam proses koreksi yaitu menentukan besar nilai Kalman gain yang ditunjukkan dalam Persamaan (15).

$$
K_{k}=P_{k}^{-} H^{T}\left(H P_{k}^{-} H^{T}+R\right)^{-1}
$$

dimana nilai $K_{k}$ merupakan Kalman gain dalam indeks waktu $k$. Nilai $P_{k}^{-}$adalah prediksi kovarian error pada waktu $k, H$ merupakan model matriks transisi dan $R$ adalah error dari pengukuran. Model matriks transisi $H$ dan $R$ ditunjukkan dalam Persamaan (16) dan (17).

$$
\begin{aligned}
H & =\left[\begin{array}{cccccc}
1 & 0 & 0 & 0 & 0 & 0 \\
0 & 0 & 1 & 0 & 0 & 0 \\
0 & 0 & 0 & 0 & 1 & 0
\end{array}\right] \\
R & =E\left(Z_{k} \cdot Z_{k}^{T}\right)=\operatorname{diag}\left[\operatorname{cov}\left(\dot{\alpha}_{x}\right) \operatorname{cov}\left(\dot{\alpha}_{y}\right) \operatorname{cov}\left(\dot{\alpha}_{z}\right)\right]
\end{aligned}
$$

nilai $R$ berisi diagonal dari kovarian derau kecepatan sudut gyroscope pada sumbu $x$, sumbu $y$, dan sumbu $z$.

Langkah kedua dalam proses koreksi yaitu update estimasi dengan pengukuran $Z_{k}$. Persamaan state ini ditunjukkan dalam Persamaan (18).

$$
\widehat{X}_{k}=\hat{X}_{k}^{-}+K_{k}\left(Z_{k}-H \hat{X}_{k}^{-}\right)
$$

dimana nilai $\hat{X}_{k}$ merupakan state dari sistem pada waktu $k, \hat{X}_{k}^{-}$adalah prediksi state dari sistem pada waktu $k, K_{k}$ adalah nilai Kalman gain, $Z_{k}$ merupakan data pengukuran dari sensor dan $H$ adalah model matriks transisi $H$.

Langkah yang terakhir dalam proses koreksi yaitu menghitung update kovarian error akhir yang ditunjukkan dalam Persamaan (19).

$$
P_{k}=\left(I-K_{k} H\right) P_{k}^{-}
$$

dimana $P_{k}$ merupakan kovarian error pada waktu $k, I$ merupakan matriks identitas $6 \times 6$, dan $P_{k}^{-}$adalah prediksi kovarian error pada waktu $k$.

Hasil dari perhitungan Kalman filter berupa grafik dari nilai $\hat{X}_{k}$ pada Persamaan (18) sedangkan perhitungan estimasi awal tanpa Kalman filter berupa grafik dari nilai $\hat{X}_{k}^{-}$pada Persamaan (11) yang kemudian hasil kedua data tersebut dibandingkan data orientasi yang merupakan algoritma bawaan pada aplikasi Sensorstream IMU+GPS.

\section{Hasil Dan Pembahasan}

\subsection{Hasil Percobaan pada Sumbu $x$ (Roll)}

Percobaan dilakukan dengan merotasikan benda terhadap sumbu $x$ selama rentang waktu 27,8 detik telah dihasilkan 418 data masukan. Hasil data tersebut, kemudian dinyatakan dalam bentuk grafik yang berfungsi untuk mempermudah pembacaan data hasil serta untuk membandingkan respon output hasil estimasi dari model yang dirancang dengan data orientasi bawaan aplikasi. Gambar grafik data hasil percobaan dapat dilihat pada Gambar 4, 5, dan 6. 


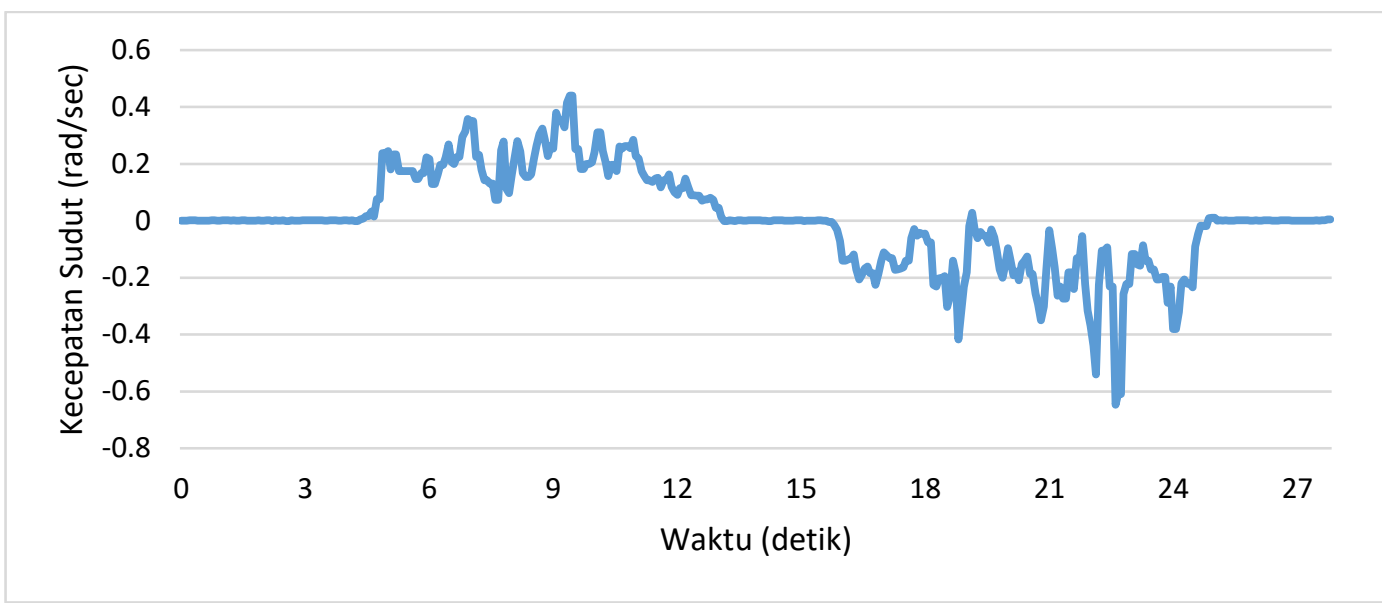

Gambar 4. Grafik data kecepatan sudut pada sumbu $x$ (roll)

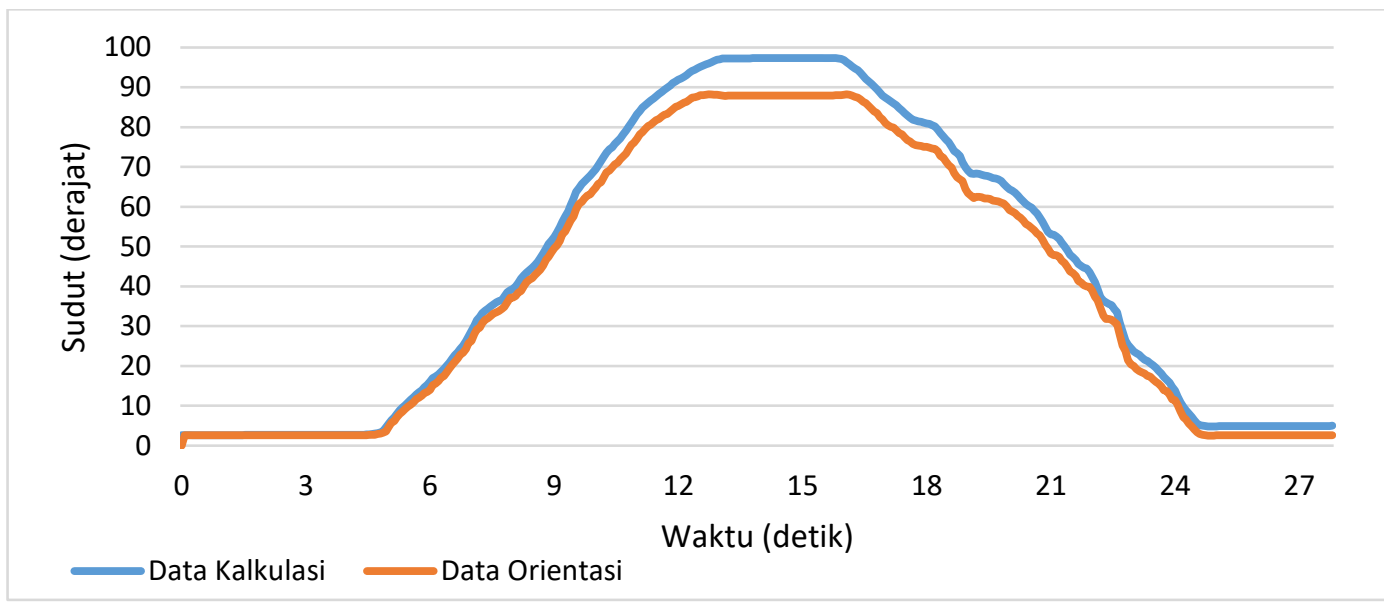

Gambar 5. Grafik data sudut roll sebelum Kalman filter vs data orientasi

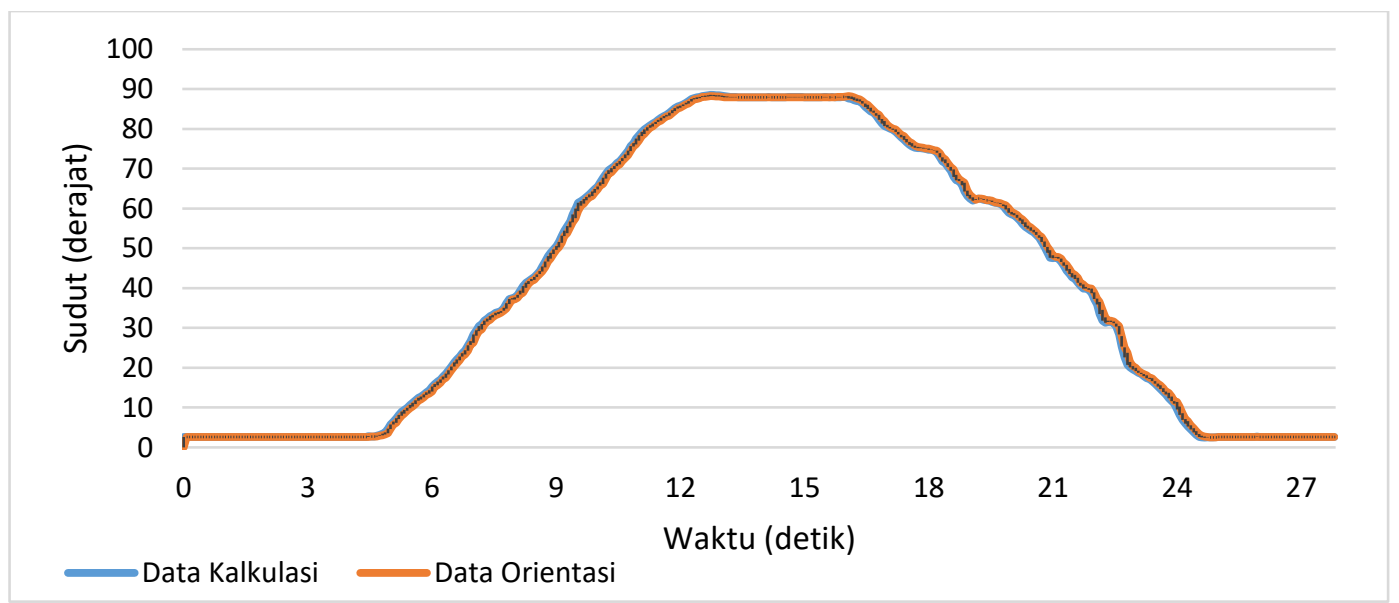

Gambar 6. Grafik data sudut roll model Kalman filter vs data orientasi

Gambar 4 merupakan grafik data output dari sensor gyroscope ketika objek/benda (smartphone) digerakkan secara rotasi tehadap sumbu $x$. Data ini merupakan data kecepatan sudut $\left(\dot{\alpha}_{x}\right)$ benda yang merupakan input dari sistem/model pada sumbu $x$. Kemudian, setelah melalui model didapatkan data hasil percobaan pada Gambar 5. Besar sudut rotasi benda didapatkan sebesar $97,337^{\circ}$ sebelum penapisan dengan Kalman filter (data kalkulasi). Hal ini menunjukkan bahwa model dinamika sistem yang dirancang dapat bekerja dengan baik 
memberikan output state nilai sudut. Sementara itu, sebagai perbandingan data orientasi didapatkan sebesar $88,207^{\circ}$.

Setelah melalui Kalman filter, data hasil percobaan ditampilkan pada Gambar 6 yang didapatkan data hasil sudut rotasi benda sebesar $88,522^{\circ}$ yang mendekati data orientasi. Hal ini menunjukkan bahwa model Kalman filter yang dirancang dapat meningkatkan akurasi estimasi data pengukuran.

\subsection{Hasil Percobaan pada Sumbu y (Pitch)}

Percobaan yang telah dilakukan terhadap sumbu $y$ selama rentang waktu 20,5 detik menghasilkan 309 data masukan. Gambar grafik data dari hasil percobaan dapat dilihat pada Gambar 7, 8, dan 9.

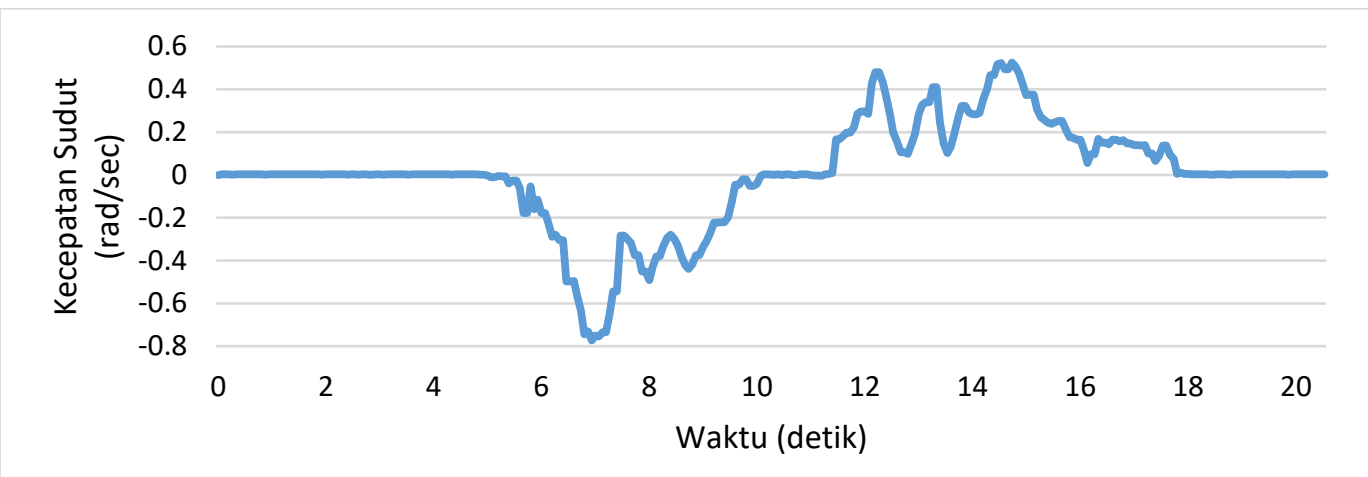

Gambar 7. Grafik data kecepatan sudut pada sumbu $y$ (pitch)

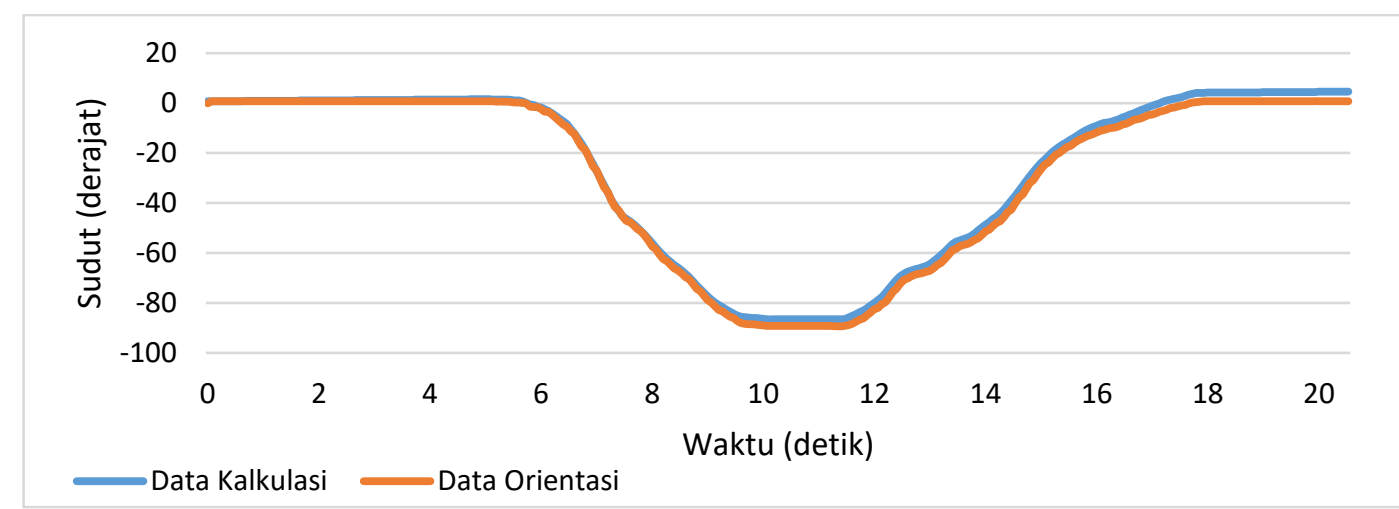

Gambar 8. Grafik data sudut pitch sebelum Kalman filter vs data orientasi

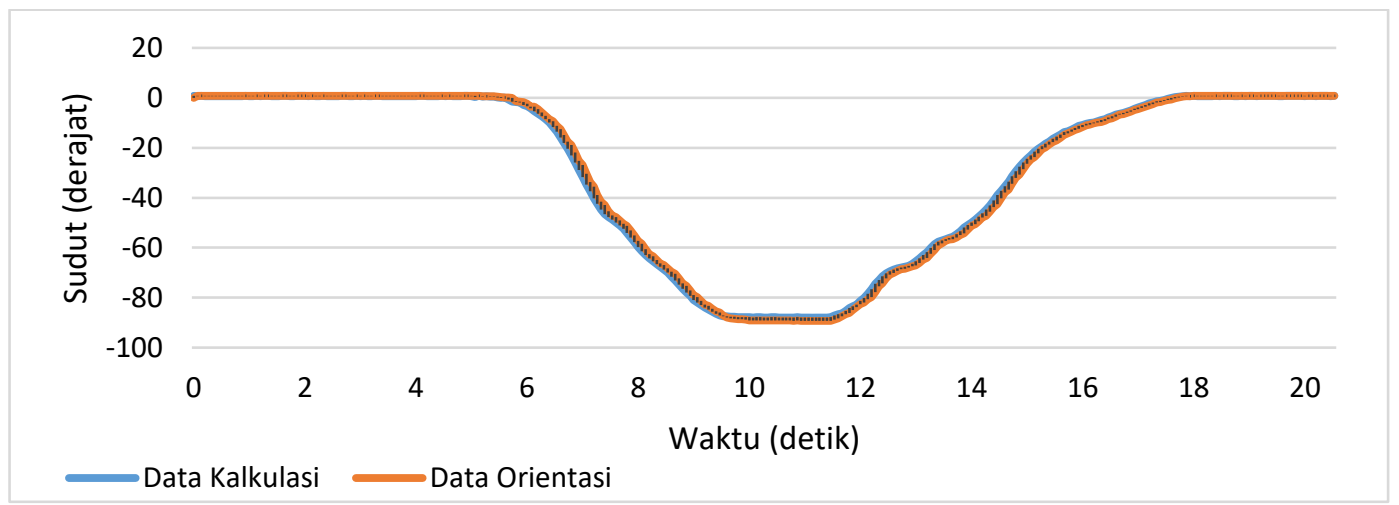

Gambar 9. Grafik data sudut pitch model Kalman filter vs data orientasi 
Gambar 7 merupakan grafik data kecepatan sudut dari sensor gyroscope yang digerakkan secara rotasi terhadap sumbu $y$. Data ini merupakan data kecepatan sudut $\left(\dot{\alpha}_{y}\right)$ benda yang merupakan input dari sistem pada sumbu $y$. Kemudian, setelah melalui model didapatkan data hasil percobaan pada Gambar 8, dimana sudut rotasi benda didapatkan sebesar $-86,584^{\circ}$ (tanda - atau + menunjukkan arah berlawanan) sebelum penapisan dengan Kalman filter (data kalkulasi). Hal ini menunjukkan bahwa model dinamika sistem yang dirancang dapat bekerja dengan baik memberikan output state nilai sudut. Dapat dilihat perbandingan dengan data orientasi yang didapatkan besar sudut rotasi sebesar $-89,292^{\circ}$.

Setelah melalui Kalman filter, data hasil percobaan ditampilkan pada Gambar 9 yang didapatkan data hasil sudut rotasi benda sebesar $-87,995^{\circ}$. Meskipun hanya beberapa derajad, model Kalman filter yang dirancang dapat meningkatkan akurasi estimasi data pengukuran.

\subsection{Hasil Percobaan pada Sumbu $z$ (yaw)}

Pada percobaan yang dilakukan terhadap sumbu $z$ menghasilkan 310 data dengan rentang waktu 20,6 detik. Gambar grafik data dari hasil percobaan dapat dilihat pada gambar 10, 11, dan 12. Gambar 10 merupakan grafik data kecepatan sudut dari sensor gyroscope yang digerakkan secara rotasi terhadap sumbu $z$. Data ini merupakan data kecepatan sudut $\left(\dot{\alpha}_{z}\right)$ benda yang merupakan input dari sistem pada sumbu z.

Kemudian, setelah melalui model didapatkan data hasil percobaan pada Gambar 11, dimana sudut rotasi benda didapatkan sebesar $-168,89^{\circ}$ (tanda - atau + menunjukkan arah berlawanan) sebelum penapisan dengan Kalman filter (data kalkulasi). Hal ini menunjukkan bahwa model dinamika sistem yang dirancang dapat bekerja memberikan output state nilai sudut. Dapat dilihat sebagai perbandingan dengan data orientasi yang didapatkan besar sudut rotasi sebesar $-161,71^{\circ}$. Dikarenakan data awal yang tidak dimulai dari 0 , maka hasil sudut pergerakan rotasi benda dari data kalkulasi dan data orientasi masing-masing dikurangi data awal dari setiap data tersebut. Sehingga, nilai akhir sudut rotasi dari data kalkulasi menghasilkan $-91,595^{\circ}$, sedangkan untuk data orientasi menghasilkan sudut pergerakan rotasi $-86,263^{\circ}$.

Setelah melalui Kalman filter, data hasil percobaan ditampilkan pada Gambar 12 yang didapatkan data hasil sudut rotasi benda sebesar $-162,69^{\circ}$ (data orientasi $-161,71^{\circ}$ ). Dikarenakan posisi awal benda tidak dimulai dari 0 , maka hasil sudut pergerakan benda dari data kalkulasi dan data orientasi masing-masing dikurangi data awal dari setiap data tersebut. Sehingga, nilai akhir dari data kalkulasi menghasilkan sudut pergerakan rotasi sebesar $-85,387^{\circ}$ sedangkan untuk data orientasi menghasilkan sudut sebesar $-86,263^{\circ}$. Dari hasil ini, menunjukkan model Kalman filter dapat meningkatkan akurasi estimasi data pengukuran.

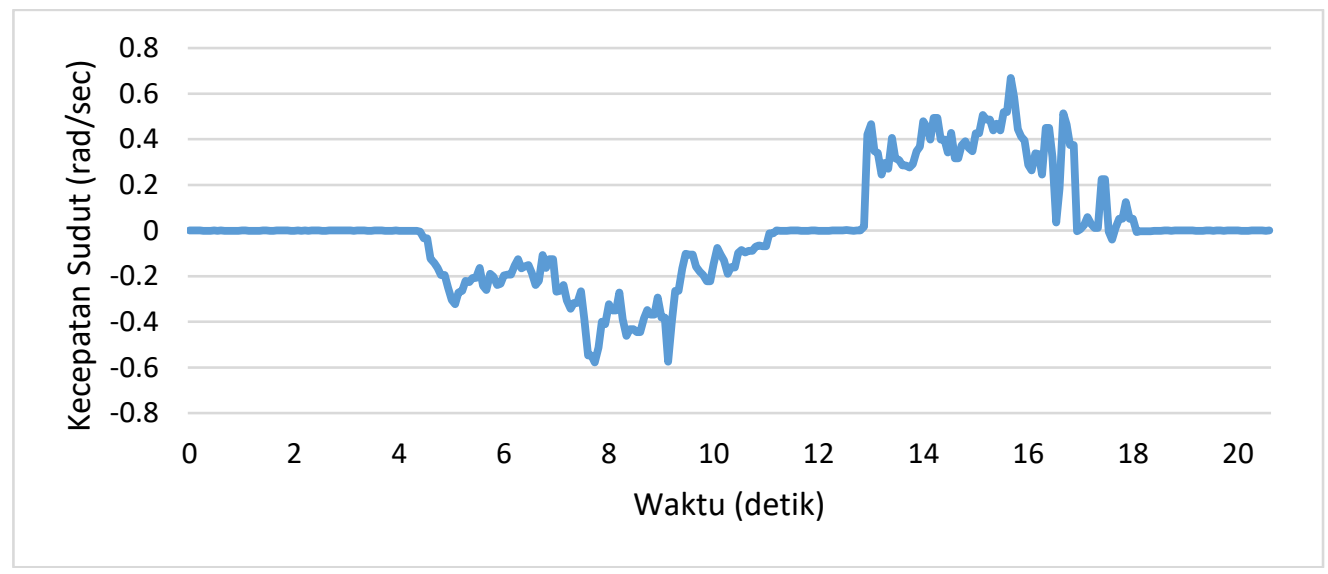

Gambar 10. Grafik data kecepatan sudut pada sumbu $z$ (yaw) 


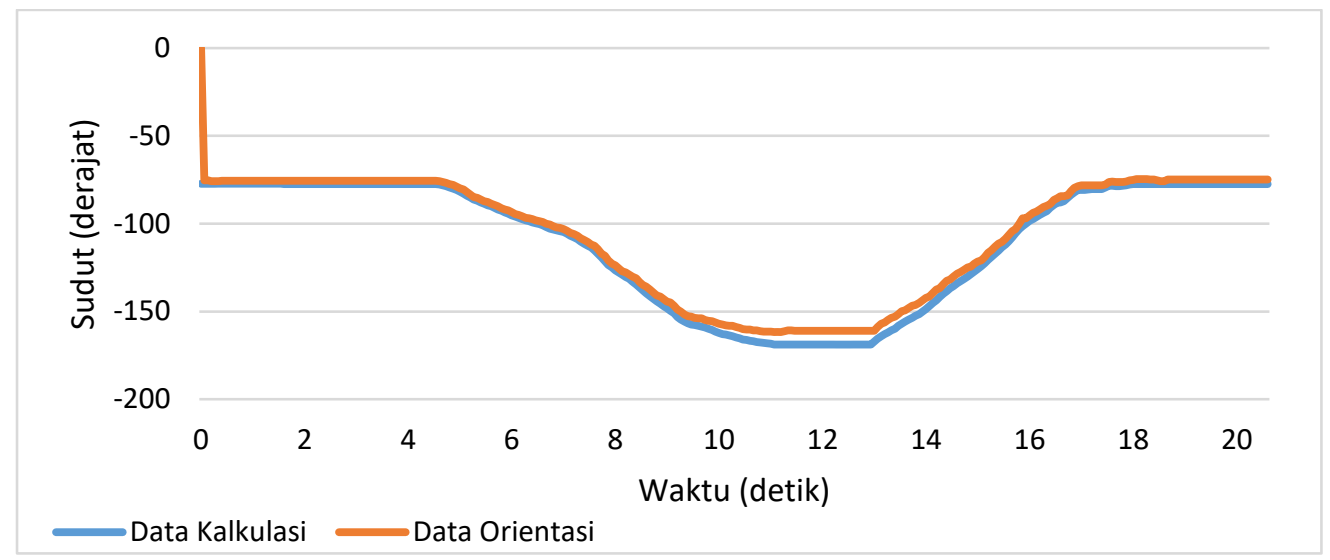

Gambar 11. Grafik data sudut yaw sebelum Kalman filter vs data orientasi

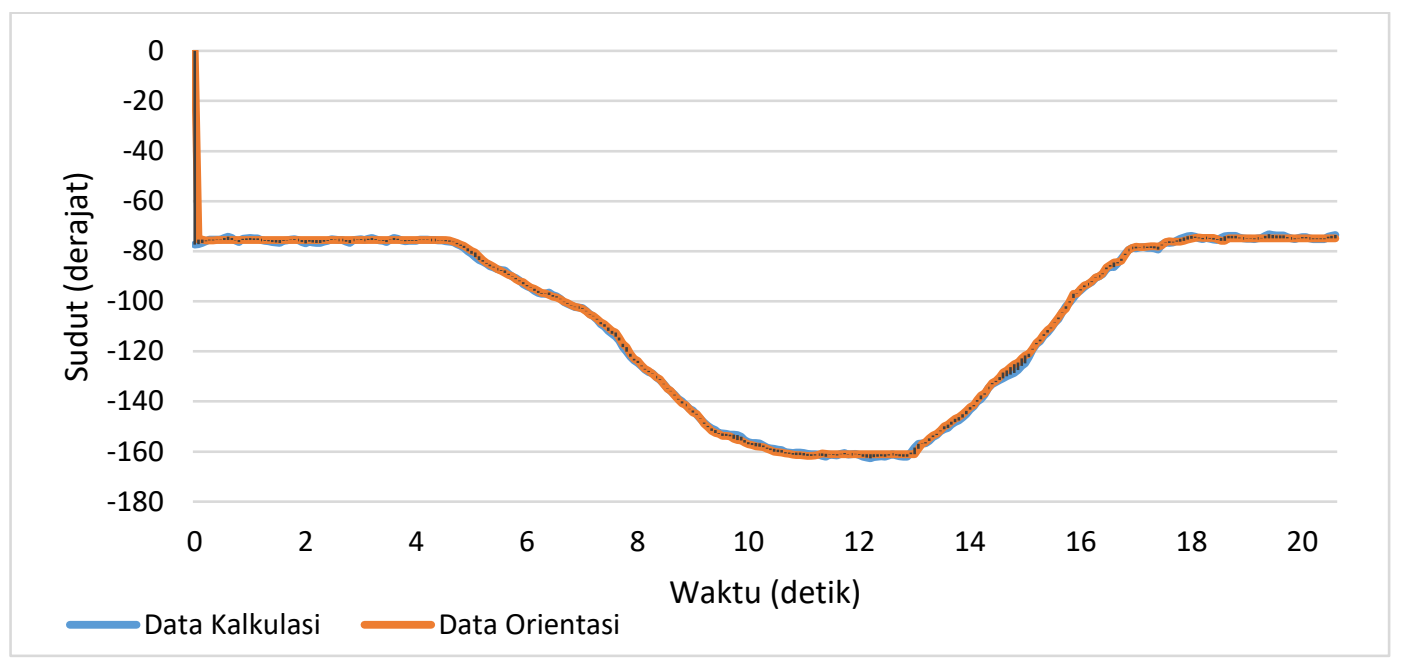

Gambar 12. Grafik data sudut yaw model Kalman filter vs data orientasi

\subsection{Analisis Akurasi Sistem}

Pada bagian ini akan dilihat ketepatan estimasi sudut pergerakan rotasi benda/objek dari model yang dirancang dengan cara menghitung galat dari data hasil percobaan dibandingkan dengan data orientasi. Untuk mencari besar galat pada penelitian ini, ditentukan dalam Persamaan (20) berikut.

$$
\text { Galat }=\left|\frac{T-P}{T}\right| \times 100 \%
$$

dimana, $T$ merupakan data orientasi dan $P$ merupakan data hasil percobaan (estimasi) dari model Kalman filter. Sedangkan untuk menghitung akurasi ditentukan dalam Persamaan (21).

$$
\text { Akurasi }=\mid 100 \%-\text { Galat } \mid
$$

dimana galat ditentukan dengan menggunakan Persamaan (20).

Adapun besar galat dan akurasi masing-masing sumbu sebelum dan sesudah penapisan dapat ditunjukkan dalam Tabel 1. 
Tabel 1. Data galat dan akurasi sebelum dan sesudah penapisan setiap sumbu

\begin{tabular}{c|c|c|c|c|c|c}
\hline & \multicolumn{2}{|c|}{ Sumbu $x($ roll $)$} & \multicolumn{2}{c|}{ Sumbu $y($ pitch $)$} & \multicolumn{2}{c}{ Sumbu $z$ (yaw) } \\
\cline { 2 - 7 } & $\begin{array}{c}\text { Sebelum } \\
\text { penapisan }\end{array}$ & $\begin{array}{c}\text { Setelah } \\
\text { penapisan }\end{array}$ & $\begin{array}{c}\text { Sebelum } \\
\text { penapisan }\end{array}$ & $\begin{array}{c}\text { Setelah } \\
\text { penapisan }\end{array}$ & $\begin{array}{c}\text { Sebelum } \\
\text { penapisan }\end{array}$ & $\begin{array}{c}\text { Setelah } \\
\text { penapisan }\end{array}$ \\
\hline Galat (\%) & 10,351 & 0,357 & 3,032 & 1,452 & 4,444 & 0,605 \\
\hline Akurasi (\%) & 89,648 & 99,642 & 96,967 & 98,547 & 95,555 & 99,394 \\
\hline
\end{tabular}

Dari Tabel 1, didapatkan nilai akurasi diatas 98\% yang berarti bahwa data estimasi hasil percobaan dari model Kalman filter sebagai tapis telah mendekati data orientasi yang digunakan sebagai data pembanding. Oleh karena itu, fungsi dari Kalman filter yang dirancang dalam penelitian ini optimal dalam mereduksi galat (error) sehingga data estimasi mempunyai akurasi yang baik.

\section{Kesimpulan}

Berdasarkan percobaan yang sudah dilakukan, model sistem yang dirancang dapat memberikan output state yang diinginkan yaitu sudut rotasi benda. Dari pengujian berbagai gerakan rotasi pada setiap sumbu, didapatkan sudut pergerakan rotasi benda sebelum penapisan sebesar $97,337^{\circ}$ pada sumbu $x$ (roll), $-86,584^{\circ}$ pada sumbu $y$ (pitch) dan $-91,595^{\circ}$ pada sumbu $z$ (yaw). Sedangkan data sudut setelah penapisan sebesar $88,522^{\circ}$ pada sumbu $x$ (roll), $-87,995^{\circ}$ pada sumbu $y$ (pitch) dan $-85,387^{\circ}$ pada sumbu $z$ (yaw). Kemudian, model Kalman filter dapat mereduksi derau dengan optimal dan dapat meningkatkan akurasi estimasi data pengukuran. Berdasarkan percobaan secara off-line, didapatkan akurasi diatas 98\%. Hasil akurasi kemungkinan bisa berbeda bila diterapkan dalam kondisi on-line (real time). Pada penelitian ini, kerangka koordinat masih dalam kerangka koordinat lokal (bodi), untuk penelitian selanjutnya kerangka koordinat dapat dibuat dalam kerangka koordinat global. Selain itu, model diharapkan dapat direalisasikan dengan perangkat keras embedded systems yang dapat diaplikasikan pada objek benda tanpa harus menggunakan smartphone.

\section{Daftar Pustaka}

[1] Fang, B., Chou, W., \& Ding, L. (2011, March). Attitude estimation of rigid bodies using MEMS inertial sensors. In 2011 Fourth International Conference on Intelligent Computation Technology and Automation (Vol. 1, pp. 592-595). IEEE.

[2] Pan, Y., Song, P., Li, K., Zhou, Y., \& Wang, Y. (2011, December). Attitude Estimation of Miniature Unmanned Helicopter Using Unscented Kalman Filter. In Proceedings 2011 International Conference on Transportation, Mechanical, and Electrical Engineering (TMEE) (pp. 1548-1551). IEEE.

[3] Lasmadi, L. (2018, November). Attitude Estimation for Quadrotor Based on IMU with Kalman-Filter. In Conference SENATIK STT Adisutjipto Yogyakarta (Vol. 4, pp. 351358).

[4] Michel, T., Geneves, P., Fourati, H., \& Layaïda, N. (2017, March). On attitude estimation with smartphones. In 2017 IEEE International Conference on Pervasive Computing and Communications (PerCom) (pp. 267-275). IEEE.

[5] Kundra, L., \& Ekler, P. (2014). Bias Compensation of Gyroscopes in Mobiles with Optical Flow. Aasri Procedia, 9, 152-157.

[6] Barton, J. D. (2012). Fundamentals of small unmanned aircraft flight. Johns Hopkins APL technical digest, 31(2), 132-149.

[7] Faragher, R. (2012). Understanding the basis of the kalman filter via a simple and intuitive derivation [lecture notes]. IEEE Signal processing magazine, 29(5), 128-132. 
[8] Ligorio, G., \& Sabatini, A. M. (2015). A novel Kalman filter for human motion tracking with an inertial-based dynamic inclinometer. IEEE Transactions on Biomedical Engineering, 62(8), 2033-2043.

[9] Wicaksono, M. A., Kurniawan, F., \& Lasmadi. (2020). Kalman Filter untuk Mengurangi Derau Sensor Accelerometer pada IMU Guna Estimasi Jarak. AVITEC, 2(2), 145-159.

[10] Lasmadi, L., Kurniawan, F., Dermawan, D., \& Pratama, G. N. (2019, December). Mobile Robot Localization via Unscented Kalman Filter. In 2019 International Seminar on Research of Information Technology and Intelligent Systems (ISRITI) (pp. 129-132). IEEE.

[11] Trimpe, S., \& D'Andrea, R. (2010, May). Accelerometer-based tilt estimation of a rigid body with only rotational degrees of freedom. In 2010 IEEE International Conference on Robotics and Automation (pp. 2630-2636). IEEE.

[12] Maarif, A., Puriyanto, R. D., \& Hasan, F. R. T. (2020). Robot Keseimbangan dengan Kendali PID dan Kalman Filter. IT Journal Research and Development, 4(2).

[13] Sandi, B. Y., Kurniawan, F., \& Lasmadi, L. (2020, December). Estimasi sudut orientasi rigid body dengan menggunakan sensor IMU (Inertial Measurement Unit) dan Magnetometer. In Conference SENATIK STT Adisutjipto Yogyakarta (Vol. 6, pp. 283294).

[14] Mudarris, M., \& Zain, S. G. (2020). Implementasi Sensor Inertial Meansurenment Unit (IMU) untuk Monitoring Perilaku Roket. Aviation Electronics, Information Technology, Telecommunications, Electricals, Controls, 2(1), 55-64.

[15] Hyde, R. A., Ketteringham, L. P., Neild, S. A., \& Jones, R. J. (2008). Estimation of upper-limb orientation based on accelerometer and gyroscope measurements. IEEE Transactions on Biomedical Engineering, 55(2), 746-754.

[16] Source. android.com. (2020). Sensor types. Dipetik September 29, 2020, dari source. android.com: https://source.android.com/devices/sensors/sensor-types 